\title{
PEMILIHAN LOKASI RUMAH SUSUN SEDERHANA SEWA: STUDI KASUS RUSUNAWA PUTRI CEMPO, SURAKARTA
}

\author{
Nona Amaliya Rahma ${ }^{1}$, Paramita Rahayu ${ }^{1}$, Ana Hardiana ${ }^{2}$ \\ ${ }_{1}$ Program Studi Perencanaan Wilayah dan Kota, Fakultas Teknik, Universitas Sebelas Maret \\ 2 Program Studi Arsitektur, Fakultas Teknik, Universitas Sebelas Maret
}

\begin{abstract}
Abstrak
Kota Surakarta memiliki luas wilayah sebesar $44,04 \mathrm{~km}^{2}$ dengan kepadatan penduduk lebih dari 11.340,84 jiwa/km². Sebagian besar permasalahan yang dihadapi Kota Surakarta adalah pertumbuhan penduduk yang cenderung mengalami peningkatan yang tidak sebanding dengan penyediaan tempat tinggal (backlog). Hal ini dipicu adanya permukiman kumuh yang perlu difasilitasi rumah layak huni. Salah satu upaya untuk mengatasi persoalan tersebut adalah penyediaan rumah susun sederhana sewa sebagai alternatif penyediaan rumah layak huni bagi MBR. Pemerintah Kota Surakarta telah membangun rusunawa di Kelurahan Mojosongo yaitu Rusunawa Putri Cempo. Namun dalam pembangunannya bukan tanpa masalah. Pada faktanya lokasi Rusunawa Putri Cempo kurang strategis karena dekat dengan aktivitas tempat pembuangan akhir (TPA), dekat perternakkan babi dan lokasi yang cenderung terpencil. Sehingga dengan adanya hal ini mengindikasi bahwa pemilihan lokasi Rusunawa Putri Cempo belum sesuai dengan teori atau regulasi yang sudah ditetapkan. Dalam pemilihan lokasi rusunawa terdapat beberapa faktor yaitu kesesuaian dengan rencana tata ruang, aksesbilitas, ketersediaan sarana, ketersediaan prasarana, harga lahan, kerawanan bencana, kondisi lingkungan dan kondisi demografi. Tujuan penelitian ini adalah untuk mengetahui tingkat prioritas faktor-faktor yang mempengaruhi pemilihan lokasi Rusunawa Putri Cempo. Penelitian ini menggunakan metode kuantitatif dengan menggunakan dua tahap analisis (1) analisis deskriptif untuk mengetahui identifikasi faktor yang mempengaruhi pemilihan lokasi Rusunawa Putri Cempo, (2) teknik Analytical Hierarchy Process (AHP) yang digunakan untuk mengetahui tingkat prioritas faktor yang mempengaruhi pemilihan lokasi Rusunawa Putri Cempo. Hasil analisis menunjukkan bahwa terdapat 4 (empat) prioritas faktor utama dalam pemilihan lokasi Rusunawa Putri Cempo menurut stakeholders yaitu kesesuaian dengan rencana tata ruang, kerawanan bencana, harga lahan dan aksesibilitas. Selain itu terdapat 4 (empat) faktor yang tidak mempunyai pengaruh besar yang juga sebagai acuan dalam pemilihan lokasi rusunawa yaitu ketersediaan sarana, ketersediaan prasarana, kondisi demografi dan kondisi lingkungan.
\end{abstract}

Kata kunci: AHP; faktor pemilihan lokasi; perumahan; rumah susun

\begin{abstract}
Surakarta is a city of $44.04 \mathrm{~km} 2$ with population density of more than $11,340.84$ inhabitatnts per km2. Housing provision is problematic for the city because supply is not able to fulfill demand for housing, or there is a backlog in Surakarta. ). Slum inhabitants contribute to the existing problem of backlog in Surakarta. . Vertical housing for low-incomecommunity is one alternative to provide livable housing for slums inhabitants. The local government has built such vertical housing in Mojosongo Village, called Rusunawa Putri Cempo. However, the location of Rusunawa Putri Cempo isclose to the city landfils, and pig farm as well as remote. Therefore, the location of Rusunawa Putri Cempo actually not yet entirely conform with the theories or regulations of housing location, which in fact should consider spatial planning, accessibility, facility, utility, land prices, disaster vulnerability, environmental conditions and demographic conditions. This research is intended to investigate the prioritizing of those housing location factors inselecting the location of Rusunawa Putri Cempo in Surakarta This study uses a quantitative method of two stages analysis (1) descriptive analysis to determine the identifcation of factors that influence the location of Rusunawa Putri Cempo (2) AHP Analysis to determine the priority of factors that influence the location of Rusunawa Putri Cempo. The results reveal that, there are four priority main factors according to the stakeholders that are spatial planning, disaster vulnerability, land prices and accessibility. In addition, there are four other factors that do not significantly affect the selection of location for Putri Cempo vertical housing. Those factors are facility, utilitiy, demographic conditions and environmental conditions.
\end{abstract}

Keywords: AHP; housing; location decision factor; vertical housing 


\section{PENDAHULUAN}

Berkembangnya tata ruang Kota Surakarta seperti kegiatan komersial di area dengan intensitas kegiatan ekonomi tinggi membuat peruntukkan lahan permukiman semakin mendesak. Hal ini mengakibatkan lahan permukiman semakin bertambah padat dan terbatas. Kota Surakarta memiliki luas wilayah sebesar 44,04 km² dengan kepadatan penduduk 11.340,84 jiwa/km². Permasalahan yang dihadapi Kota Surakarta saat ini adalah penyediaan kebutuhan tempat tinggal bagi MBR yang belum mampu menjangkau tempat tinggal. Selain itu, pertumbuhan penduduk yang terus meningkat tidak sebanding dengan penyediaan tempat tinggal (backlog). Hal ini dipicu adanya permukiman kumuh baik di bantaran rel kereta api maupun bantaran sungai sehingga perlu difasilitasi dengan rumah layak huni.

Untuk mengatasi permasalahan tersebut, Pemerintah Kota Surakarta merumuskan program pembangunan perumahan khusus untuk MBR salah satunya adalah pembangunan rusunawa. Pembangunan rusunawa ini bertujuan untuk memperbaiki kualitas perumahan yang layak huni. Selain itu, pembangunan rusunawa juga untuk memaksimalkan ketersediaan lahan di Kota Surakarta yang semakin terbatas. Saat ini pemerintah Kota Surakarta telah membangun 18 tower rusunawa yang tersebar dengan karakteristik lokasi yang berbeda-beda. Misalnya Rusunawa Semanggi dekat dengan pusat perdagangan, Rusunawa Begalon dekat dengan pusat kota dan Rusunawa Jurug dekat dengan pusat aktivitas pendidikan (Rusdiono, 2012).

Pada awal tahun 2018 pemerintah Kota Surakarta membangun 2 tower rusunawa Putri Cempo di Kelurahan Mojosongo yaitu blok $C$ dan $D$ yang sebelumnya sudah terdapat 2 tower rusunawa yaitu blok $A$ dan $B$. Rusunawa ini dibangun untuk dapat ditinggali oleh MBR yang belum mempunyai hunian dengan layak dan masyarakat yang terkena dampak relokasi Kali Pepe dan Kali Anyar. Namun, pada saat pembangunan Rusunawa Putri Cempo bukan tanpa masalah. Faktanya lokasi rusunawa ini berada dalam radius dekat dengan tempat pembuangan akhir (TPA) Putri Cempo dan perternakkan babi.

Menurut Lusht (1997) mengemukakan bahwa kenyamanan dan keamanan dari suatu tempat tinggal ditentukan oleh lokasinya yaitu lingkungan dan aksesibilitas. Selain itu, lokasi Rusunawa Putri Cempo cenderung terpencil. Diikuti dengan pendapat lainnya mengenai pemilihan lokasi perumahan vertikal yaitu perlu mempertimbangkan kebersihan lingkungan, aksesibilitas menuju pusat kota dan jarak menuju fasilitas umum (Balbontin, de Dios Ortuzar dan Swait, 2014). Dari segi aksesibilitas, pembangunan rusunawa dimaksudkan untuk mengatasi masalah hunian MBR yang memiliki keterbatasan biaya yang dipandang tidak terlalu menguntungkan dan juga tidak menghasilkan keuntungan. Beberapa aspek penunjang dalam pemenuhan rumah bagi MBR adalah memberikan perlindungan hukum, keamanan dan kenyaman, aksesibilitas, layak huni, penyediaan fasilitas, dan lokasi yang terbuka terhadap pekerjaan. Di samping itu, pemilihan lokasi tempat tinggal tidak didirikan di tempat yang telah atau segera terpolusi yang bisa membuat ketidaknyamanan bagi para penghuni (Syarif, 2000). Tidak dapat dipungkiri juga bahwa harga lahan di dekat TPA cenderung murah sehingga dapat mempengaruhi pemilihan lokasi Rusunawa Putri Cempo dengan orientasi konsumen menengah ke bawah.

Pelaksanaan pembangunan rusunawa perlu mempertimbangkan aspek pemilihan lokasi karena akan berdampak pada kesejahteraan dan kenyamanan penghuni. Terlebih rusunawa tersebut nantinya akan ditempati oleh masyarakat menengah ke bawah. Keberadaan rusunawa di Kota Surakarta tentu tidak terlepas dari faktor pendukung salah satunya adalah faktor pemilihan lokasi. Berdasarkan permasalahan terkait pemilihan lokasi Rusunawa Putri Cempo mengindikasi belum mempertimbangkan aspek pemilihan lokasi yang sesuai dengan teori dan regulasi yang ada oleh stakeholders yang berkaitan dalam pembangunan rusunawa. Dengan demikian, penelitian ini dilakukan utuk mengetahui factor-faktor apa yang mempengaruhi pemilihan lokasi Rusunawa Putri Cempo berdasarkan preferensi pemerintah.

\section{KAJIAN LITERATUR}

\subsection{PENGERTIAN PERUMAHAN}

Berdasarkan Undang-Undang No. 1 tahun 2011 tentang Perumahan dan Kawasan Permukiman menyebutkan pengertian perumahan adalah kumpulan rumah yang merupakan bagian dari permukiman, baik daerah perkoaan maupun perdesaan yang dilengkapi dengan sarana, prasarana dan utilitas lingkungan. Menurut SNI Tata cara perencanaan lingkungan perumahan di perkotaan, perumahan adalah kelompok rumah yang berfungsi sebagai tempat tinggal yang dilengkapi dengan prasarana dan sarana lingkungan. Rumah dapat dikatakan sebagai bangunan yang berfungsi sebagai tempat tinggal atau 
hunian dan sarana pembinaan keluarga. Kebutuhan manusia terhadap perumahan memiliki dua artian yaitu, pertama sebagai komoditi yang mana standar fisik rumah yang tepat untuk dijadikan kriteria pengukuran, dan kedua adalah sebagai rumah tersebut dapat memberikan kepuasan kepada penghuninya (Turner,1976).

\subsection{PEMILIHAN LOKASI PERUMAHAN}

Pemilihan lokasi perumahan perlu mempertimbangkan berbagai faktor pendukung seperti peraturan, kondisi tanah, fasilitas pelayanan dan prasarana lingkungan dan aksesibilitas. Menurut Komarudin (1997) menjelaskan ada beberapa faktor pemilihan lokasi perumahan yaitu kemudahan aksesibilitas, tersedia fasilitas umum, terhindar dari bencana, sesuai dengan arahan pemanfataan ruang. Pedoman Kriteria Teknis Penataan Ruang Kawasan Budidaya (2007) menyebutkan bahwa pertimbangan dalam pemilihan lokasi perumahan yaitu topografi, prasarana, bukan daerah rawan banjir, dan bukan pada kawasan lindung. Pertimbangan lain menurut Nasucha (1995) menjelaskan bahwa harga lahan untuk perumahan yang berada di pinggiran kota cenderung lebih murah dibanding dengan harga lahan di dekat pusat kota. Menurut Lusht (1997) mengungkapkan bahwa pemilihan lokasi perumahan ditentukan oleh kondisi lingkungan dan aksesibilitas. Berdasarkan SNI 03-1733-2004 dalam memilih lokasi perumahan harus sesuai dengan rencana tata ruang wilayah, tidak berada di daerah yang mempunyai pencemaran udara, air dan kebisingan, aksesibilitas, aman dari bencana, dan kemiringan lahan tidak melebihi 08\%. Pemilihan lokasi perumahan menurut Catanese, dkk (1991) meliputi sah secara hukum, ketersediaan prasarana, estetika, harga lahan, topografi, dan aksesibilitas. Menurut Drabkin (1980) dalam memilih lokasi perumahan terdiri dari aksesibilitas, lingungan fisik dan sosial, aksesibilitas dan tersedia sarana prasarana. Lokasi perumahan perlu mempertimbangkan kondisi lingkungan yang terhindar dari polusi, aman dan kelengkapan sarana (Turner, 1976). Adapun persyaratan pemilihan lokasi perumahan menurut Budihardjo (2004') yaitu bukan daerah rawan bencana, aksesibilitas terlayani sarana dan prasarana, lokasi jauh dari pencemaran dan kebisingan. Sedangkan persyaratan lokasi perumahan menurut Keputusan Menteri Kesehatan yaitu ketersediaan sarana dan prasarana, aksesibilitas, aman dari bencana, tidak terganggu oleh kebisingan dan terhindar dari polusi.

\subsection{PENGERTIAN RUMAH SUSUN}

Kebijakan penyelenggaraan perumahan dan permukiman telah diatur dalam Undang-Undang Nomor 1 tahun 2011 tentang Perumahan dan Kawasan Permukiman. Adanya kebijakan tersebut merupakan salah satu kebutuhan pokok bagi seluruh lapisan masyarakat agar mampu bertempat tinggal dengan layak huni dan terjangkau dalam lingkungan yang sehat, aman, harmonis dan berkelanjutan. Pembangunan perumahan meliputi rumah tunggal, rumah deret dan rumah susun. Pemerintah daerah wajib memberikan kemudahan akses bagi MBR untuk menjangkau perumahan. Salah satu program pemerintah daerah dalam menyediakan hunian bagi MBR yaitu pembangunan rumah susun. Pembangunan rumah susun pada dasarnya diarahkan untuk meningkatkan kualitas hunian layak huni yang didukung dengan lingkungan sehat dan berkelanjutan. Dalam upaya peningkatan kualitas perumahan dan permukiman kumuh, pemerintah daerah menetapkan kebijakan dan pola penanganannya dalam bentuk pemugaran, peremajaan dan permukiman kembali. Pembangunan rumah susun merupakan salah satu pola penanganan peremajaan kota bagi daerah yang kumuh. Di samping itu juga untuk memecahkan persoalan pemenuhan kebutuhan terhadap tempat tinggal yang terjangkau bagi seluruh lapisan masyarakat terutama di kawasan perkotaan yang mempunyai jumlah penduduk yang selalu meningkat, mengingat lahan diperkotaan semakin berkutang. Pengertian rumah susun berdasarkan Undang - Undang No. 1 Tahun 2011 tentang Perumahan dan Kawasan Permukiman menyebutkan adalah tempat tinggal yang diatur secara bertingkat. Rumah susun adalah bangunan bertingkat yang dibangun secara vertikal dalam suatu lingkungan yang distrukturkan secara fungsional, digunakan secara terpisah teutama tempat hunian yang sudah dilengkapi benda dan tanah bersama. Pengertian rumah susun berdasarkan Undang-Undang No. 20 tahun 2011 tentang Rumah Susun yaitu bangunan secara vertikal di suatu lingkungan yang dapat dihuni secara masing-masing dan digunakan secara terpisah.

\subsection{PEMILIHAN LOKASI RUMAH SUSUN}

Perencanaan dan pembangunan rumah susun tidak terlepas dari pemilihan lokasi yang sudah ditetapkan oleh pihak-pihak yang ikut terlibat dalam penyelenggaraan rumah susun. Berdasarkan Permen PUPR tentang Bantuan Pembangunan dan Pengelolaan Rumah Susun menyebutkan bahwa pemilihan lokasi rumah susun harus memperhatikan rencana tata ruang, aksesibilitas, bebas dari bencana, terlayani prasarana dan utilitas umum. Menurut Peraturan Menteri 21 tahun 2011 tentang 
Pedoman Bantuan Pembangunan Rumah Susun Sewa, lokasi rumah susun harus memenuhi persyaratan yaitu sesuai dengan rencana tata ruang, aksesibilitas, terhindar dari bencana, tersedia akses, serta terlayani utilitas umum. Berdasarkan UU No, 20 tahun 2011 tentang Rumah Susun menyebutkan bahwa pemilihan lokasi rumah susun harus memenuhi syarat yaitu sesuai dengan rencana tata ruang, kepadatan bangungan dan kepadatan penduduk, serta layanan sarana dan prasarana. Berdasarkan Tata Cara Perencanaan Fasilitas Lingkungan Rumah Susun Sederhana dalam pemilihan lokasi rumah susun perlu mempertimbangkan aspek topografi, akses terhadap fasilitas umum, tidak berada di sekitar lokasi yang mempunyai pencemaran, kepadatan bangunan, dan bukan daerah rawan bencana. Menurut Balbontin, de Dios Ortuzar dan Swait (2014) faktor pemilihan lokasi perumahan vertikal mempertimbangkan kebersihan lingkungan, aksesibilitas menuju pusat kota dan jarak menuju fasilitas umum. Menurut Williams (2008) dalam Ahmad Ezanee Hashim dkk, (2012) karakteristik lokasi melihat ketersediaan transportasi umum dan keterjangkauan terhadap fasilitas umum. Mengacu pada pendapat para ahli, sintesis variabel penelitian dapat dilihat pada Tabel 1.

Tabel 1. Sintesis Variabel Penelitian

\begin{tabular}{|c|c|c|c|}
\hline $\begin{array}{l}\text { Variabel Lokasi } \\
\text { Rumah Susun }\end{array}$ & $\begin{array}{l}\text { Variabel Lokasi } \\
\text { Perumahan }\end{array}$ & $\begin{array}{l}\text { Sintesis Variabel } \\
\text { Pemilihan Lokasi } \\
\text { Rumah Susun }\end{array}$ & Penjabaran Variabel \\
\hline Rencana tata ruang & $\begin{array}{l}\text { Sesuiai rencana tata } \\
\text { ruang }\end{array}$ & $\begin{array}{l}\text { Kesesuaian rencana tata } \\
\text { ruang }\end{array}$ & $\begin{array}{l}\text { Pemilihan lokasi rumah susun harus sesuai dengan } \\
\text { peruntukan kawasan budidaya perumahan } \\
\text { berdasarkan RTRW }\end{array}$ \\
\hline $\begin{array}{l}\text { Terhindar } \\
\text { bencana }\end{array}$ & Tidak rawan bencana & Kerawanan bencana & $\begin{array}{l}\text { Pemilihan lokasi rumah susun tidak berada pada } \\
\text { daerah rawan rencana }\end{array}$ \\
\hline $\begin{array}{l}\text { Sarana } \\
\text { Prasarana }\end{array}$ & $\begin{array}{l}\text { Ketersediaan sarana } \\
\text { dan prasarana }\end{array}$ & $\begin{array}{l}\text { Ketersediaan sarana } \\
\text { Ketersediaan prasarana }\end{array}$ & $\begin{array}{l}\text { Ketersediaan sarana dan prasarana penunjang } \\
\text { sangat penting dalam pemilihan lokasi rumah susun } \\
\text { maupun perumahan }\end{array}$ \\
\hline Aksesibilitas & Aksesibilitas & Aksesibilitas & $\begin{array}{l}\text { Pemilihan lokasi rumah susun perlu } \\
\text { mempertimbangkan aksesibilitas yang didukung } \\
\text { dengan jarak ke fasilitas umum, ketersediaan moda } \\
\text { transportasi dan jarak ke jalan utama atau jalan raya }\end{array}$ \\
\hline Kondisi demografi & - & Kondisi demografi & $\begin{array}{l}\text { Kondisi demografi ditinjau dari segi jumlah } \\
\text { penduduk dan luas wilayah terbangun yang mampu } \\
\text { untuk dibangun rumah susun }\end{array}$ \\
\hline Kondisi lingkungan & Kondisi lingkungan & Kondisi lingkungan & $\begin{array}{l}\text { Pemilihan lokasi rumah susun perlu } \\
\text { mempertimbangkan kesehatan lingkungan yang } \\
\text { artinya daerah tersebut tidak mempunyai aktivitas } \\
\text { yang menyebabkan pencemaran udara, air dan } \\
\text { kebisingan }\end{array}$ \\
\hline- & Harga lahan & Harga lahan & $\begin{array}{l}\text { Harga lahan di pusat kota lebih mahal dibandingkan } \\
\text { dengan harga lahan yang berada di pinggiran yang } \\
\text { cenderung murah }\end{array}$ \\
\hline
\end{tabular}

\section{METODE PENELITIAN}

Penelitian ini menggunakan pendekatan deduktif dengan jenis penelitian kuantitatif. Tujuan dari penelitian ini untuk mengetahui faktor prioritas yang mempengaruhi pemilihan lokasi Rusunawa Putri Cempo. Teknik pengumpulan data yang dilakukan terbagi menjadi 2 yaitu pengumpulan data primer dengan observasi lapangan, memberikan kuesioner AHP kepada stakeholders terkait pembangunan rusunawa untuk mendapatkan nilai kepentingan tiap faktor dan pengumpulan data sekunder dengan studi dokumen atau literature dari instansi terkait. Variabel dan indikator pada penelitian dapat dilihat pada Tabel 2.

Pada penelitian ini menggunakan teknik purposive sampling. Hal ini dikarenakan bahwa dalam pemilihan lokasi Rusunawa Putri Cempo dibutuhkan data sekunder yang didapatkan dari instansi terkait. Salah satu strategi analisis dari teknik purposive sampling adalah analisis stakeholder mapping. Analisis ini digunakan karena dibutuhkan pakar atau pendapat ahli yang memiliki kemampuan pada penelitian ini. Untuk menentukkan pihak-pihak yang terkait dalam penelitian ini maka dilakukan studi dokumen berdasarkan tupoksi dalam Perwali Surakarta No 27-C Tahun 2016 tentang Kedudukan, Susunan Organisasi, 
Tugas, Fungsi dan Tata Kerja Perangkat Daerah Kota Surakarta yang menangani pembangunan Rusunawa Putri Cempo. Setelah itu, penentuan justifikasi pengaruh dan kepentingan dilakukan melalui analisis stakeholder mapping terkait pihak yang terlibat dalam pemilihan lokasi Rusunawa Putri Cempo. Gambar 1 adalah hasil stakeholder mapping berdasarkan pengaruh dan kepentingan dalam pemilihan lokasi Rusunawa Putri Cempo.

Tabel 2. Variabel Penelitian

\begin{tabular}{|c|c|c|}
\hline Variabel & Indikator & Sumber \\
\hline $\begin{array}{l}\text { Kesesuaian rencana tata } \\
\text { ruang }\end{array}$ & 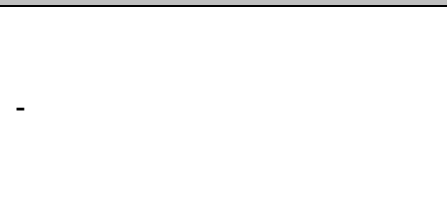 & $\begin{array}{l}\text { Permen PUPR No. 01/PRT/M/2018 tentang Bantuan } \\
\text { Pembangunan dan Pengelolaan Rumah Susun, Permen } \\
\text { No. } 21 \text { tahun } 2011 \text { tentang Pedoman Bantuan } \\
\text { Pembangunan Rumah Susun Sewa, UU No. } 20 \text { tahun } \\
2011 \text { tentang Rumah Susun }\end{array}$ \\
\hline Kerawanan bencana & Longsor & $\begin{array}{l}\text { Komarudin (1997), Budihardjo (2004), Pembangunan Dan } \\
\text { Pengelolaan Rumah Susun, dan SNI Tata Cara } \\
\text { Perencanaan Fasilitas Lingkungan Rumah Susun } \\
\text { Sederhana }\end{array}$ \\
\hline Aksesibilitas & $\begin{array}{l}\text { Jarak menuju fasilitas umum } \\
\text { Ketersediaan transportasi umum } \\
\text { Jarak menuju jalan utama/jalan } \\
\text { raya }\end{array}$ & $\begin{array}{l}\text { Permen No. } 21 \text { tahun 2011, Turner (1976), Rapopor } \\
\text { (1983), Balbontin, de Dios Ortuzar dan Swait (2014), } \\
\text { Williams (2008) dalam Ahmad Ezanee Hashim dkk, (2012 }\end{array}$ \\
\hline Ketersediaan sarana & $\begin{array}{l}\text { Sarana pendidikan } \\
\text { Sarana niaga/ekonomi } \\
\text { Sarana pemerintahan/pelayanan } \\
\text { umum } \\
\text { Sarana kesehatan }\end{array}$ & \\
\hline & $\begin{array}{l}\text { Sarana ruang terbuka } \\
\text { Sarana kebudayaan dan rekreasi } \\
\text { Jaringan listrik } \\
\text { Jaringan drainase } \\
\text { Jaringan persampahan }\end{array}$ & $\begin{array}{l}\text { SNI Tata Cara Perencanaan Lingkungan Perumahan d } \\
\text { Perkotaan, SNI Tata Cara Perencanaan Fasilitas } \\
\text { Lingkungan Rumah Susun Sederhana, Revi dan Dube } \\
\text { 1999), dan De'Chiara (1995) }\end{array}$ \\
\hline Ketersediaan prasarana & $\begin{array}{l}\text { Telekomunikasi } \\
\text { Jaringan air bersih } \\
\text { Sanitasi } \\
\text { Jaringan jalan }\end{array}$ & \\
\hline Kondisi demografi & Kepadatan penduduk & $\begin{array}{l}\text { SNI Tata Cara Perencanaan Lingkungan Perumahan d } \\
\text { Perkotaan, UU No. } 20 \text { tahun } 2011 \text { tentang Rumah Susun } \\
\text { dan SNI Tata Cara Perencanaan Fasilitas Lingkungan } \\
\text { Rumah Susun Sederhana }\end{array}$ \\
\hline \multirow{2}{*}{ Kondisi lingkungan } & $\begin{array}{l}\text { Udara } \\
\text { Air }\end{array}$ & \multirow{2}{*}{$\begin{array}{l}\text { Drabkin (1980), SNI Tata Cara Perencanaan Lingkungan } \\
\text { Perumahan di Perkotaan, Turner (1976), Budihardjo } \\
\text { (2004), Kepmenkes No. 829/Menkes/SK/VII/1999 dan } \\
\text { Balbontin, de Dios Ortuzar dan Swait (2014). }\end{array}$} \\
\hline & Kebisingan & \\
\hline Harga lahan & - & Nasucha (1995), Catanese, dkk (1991). \\
\hline
\end{tabular}

Berdasarkan gambar stakeholders mapping (Gambar 1) diketahui bahwa terdapat tiga kelompok karakteristik stakeholder yaitu keyplayer, subject dan context setter dengan total sampel responden yang dibutuhkan pada dalam penelitian ini sebanyak 13 sampel. Setelah itu, teknik analisis yang digunakan adalah teknik Analytical Hierarchy Process (AHP) yang diperlukan untuk mengetahui prioritas faktor yang mempengaruhi pemilihan lokasi Rusunawa Putri Cempo. Tabel 3 adalah daftar tabel responden penelitian kuisioner AHP. 


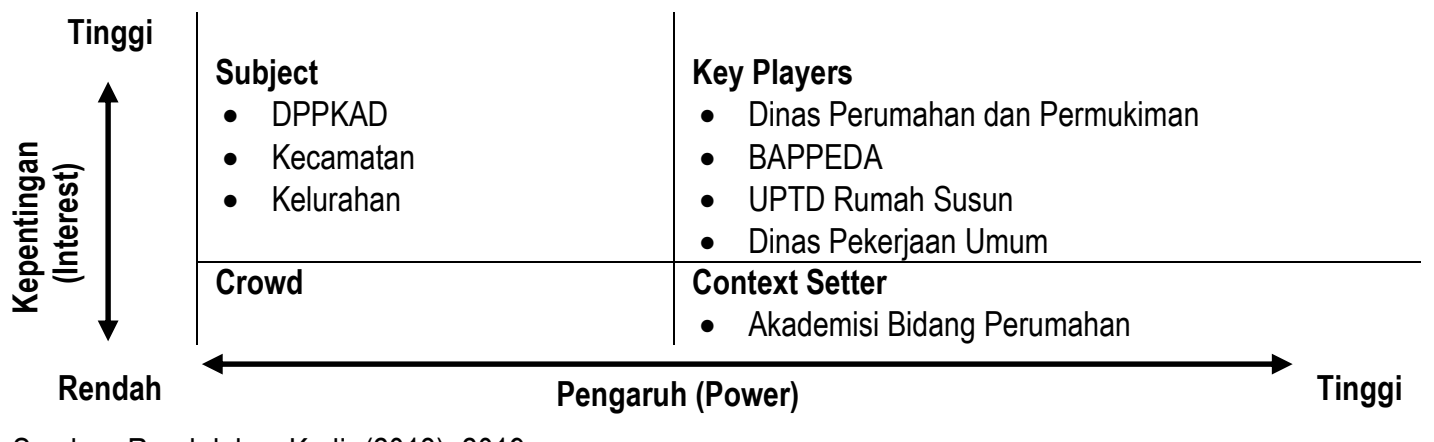

Sumber: Reed dalam Kadir (2013), 2019

Gambar 1. Matriks Stakeholders Mapping Berdasarkan Tingkat Pengaruh dan Tingkat Kepentingan

Tabel 3. Daftar Jumlah Responden

\begin{tabular}{lc}
\multicolumn{1}{c}{ Stakeholder } & Jumlah \\
\hline Instansi Pemerintah & \\
Dinas Perumahan dan Permukiman & 3 \\
Dinas Pekerjaan Umum & 3 \\
BAPPEDA & 2 \\
UPTD Rumah Susun & 1 \\
DPPKAD & 1 \\
Kecamatan & 1 \\
Kelurahan & 1 \\
Akademisi & \\
Bidang Perumahan & 2 \\
TOTAL & 13 \\
\hline
\end{tabular}

\section{HASIL DAN PEMBAHASAN}

\subsection{GAMBARAN UMUM RUSUNAWA PUTRI CEMPO}

Rusunawa Putri Cempo merupakan program dari Pemerintah Kota yang diajukan ke Pemerintah Pusat (Kementerian PUPR) dalam rangka mewujudkan pembangunan rusunawa untuk kepentingan MBR. Rusunawa Putri Cempo merupakan sebuah hunian verikal yang pembangunannya diperuntukkan bagi masyarakat berpenghasilan rendah (MBR) yang belum mampu mengakses rumah secara terjangkau sekaligus bagi masyarakat di bantaran kali yang tedampak program pengendalian banjir di Kota Surakarta sekaligus memfasilitasi kebutuhan rumah bagi masyarakat yang terkena dampak kegiatan resistensi Bendung Karet Tirtonadi. Selain itu pembangunan Rusunawa Putri Cempo merupakan salah satu kebijakan pemerintah Kota Surakarta untuk mendukung pengembangan wilayah Solo Utara. Hal ini diharapkan agar wilayah Solo Utara menjadi berkembang dengan upaya pemerataan infrastruktur berupa hunian rumah susun sederhana sewa.

Rusunawa Putri Cempo berada di sekitar permukiman penduduk yang terletak di Desa Ngemplak RW XI RT 03 Kelurahan Mojosongo, Kecamatan Jebres (lihat Gambar 2). Rumah susun ini dikenal dengan Rusunawa Putri Cempo karena letaknya yang tidak jauh dari tempat pembuangan akhir Putri Cempo. Rusunawa ini terbagi menjadi 4 blok dengan masing-masing memiliki empat lantai yaitu blok A yang dibangun tahun 2016, blok B pada tahun 2017 sedangkan Blok $C$ dan D yang dibangun pada tahun 2018 hingga sekarang sudah rampung dan sudah dihuni.

\subsection{IDENTIFIKASI FAKTOR PEMILIHAN LOKASI RUSUNAWA PUTRI CEMPO}

\subsubsection{Kerawanan Bencana}

Faktor kerawanan bencana termasuk hal yang sangat penting dilakukan dalam pemilihan lokasi rusunawa. Kerawanan bencana yang diteliti pada peneilitian ini adalah banjir dan longsor. 
a) Banjir

Berdasarkan RTRW Kota Surakarta Tahun 2011-2031, Rusunawa Putri Cempo yang terletak di Kelurahan Mojosongo bukan termasuk dalam daerah rawan banjir. Hal ini didukung dengan kontur di Kelurahan Mojosongo yang relatif tinggi sehingga aman dari bahaya banjir.

b) Longsor

Berdasarkan data Kecamatan Jebres Dalam Angka tahun 2018 diketahui bahwa Kelurahan Mojosongo mempunyai kemiringan lereng, yakni sebesar 0-40 \%. Kondisi tersebut tergolong dalam kategori curam. Untuk kawasan Rusunawa Putri Cempo dibangun di atas lahan dengan kemiringan tanah (Slope of Land) yang bergelombang yaitu 10-15\% yang berisiko rawan terhadap bahaya longsor.

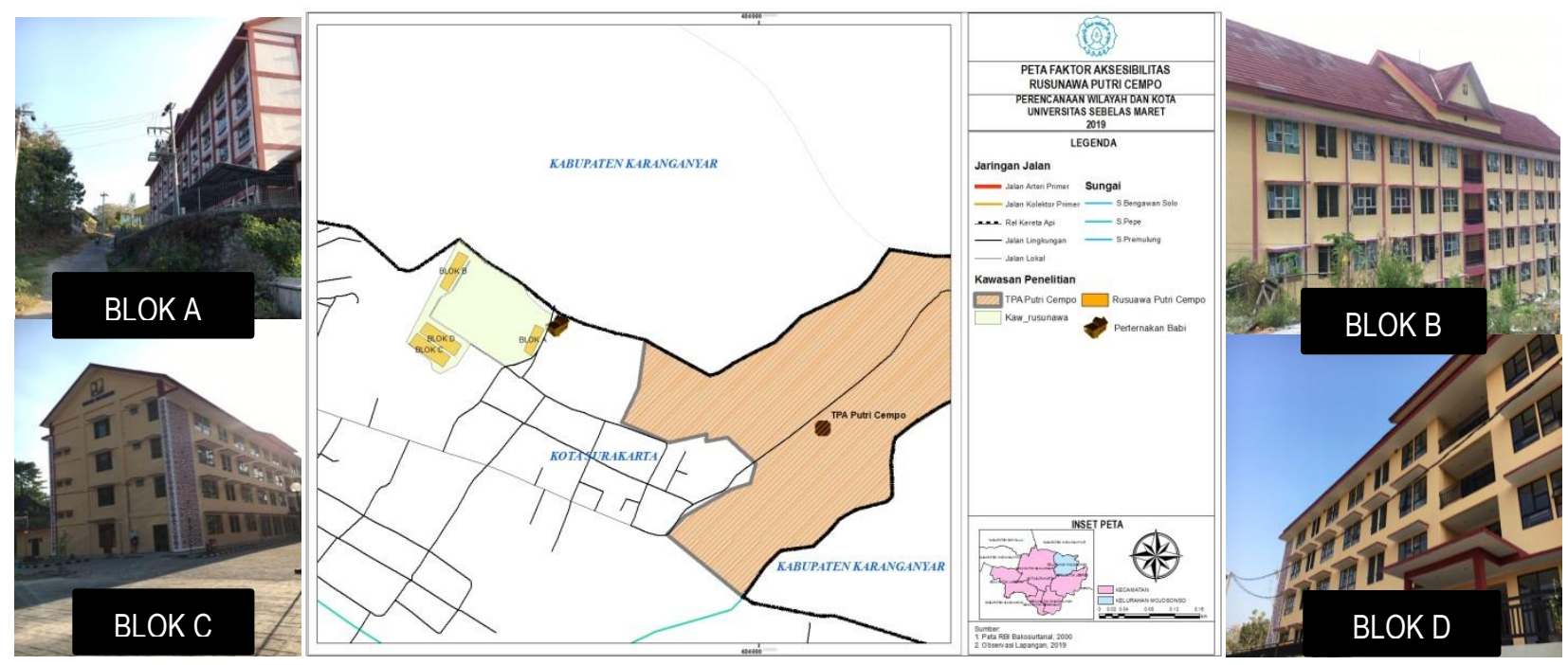

Gambar 2. Peta Lokasi Rusunawa Putri Cempo

\subsubsection{Kesesuaian dengan Rencana Tata Ruang}

Berdasarkan Perda No. 1 Tahun 2012 tentang RTRW Kota Surakarta Tahun 2011-2031 terkait kawasan budidaya untuk peruntukkan kawasan perumahan dan permukiman telah dijelaskan dalam pasal 43 ayat 2 yang menyebutkan bahwa kawasan budidaya untuk pengembangan perumahan vertikal berupa rumah susun sewa (rusunawa) akan dikembangkan di Kecamatan Jebres dan Kecamatan Serengan (lihat Gambar 3). Berdasarkan isi Perda tersebut menerangkan bahwa lokasi Rusunawa Putri Cempo yang terletak di Kecamatan Jebres merupakan daerah yang ditetapkan dalam perencanaan perumahan vertikal atau rumah susun sewa (rusunawa). Sehingga dari hasil observasi dapat diketahui bahwa lahan yang digunakan untuk membangun Rusunawa Putri Cempo telah sesuai dengan Rencana Tata Ruang dengan peruntukkan kawasan budidaya perumahan. 


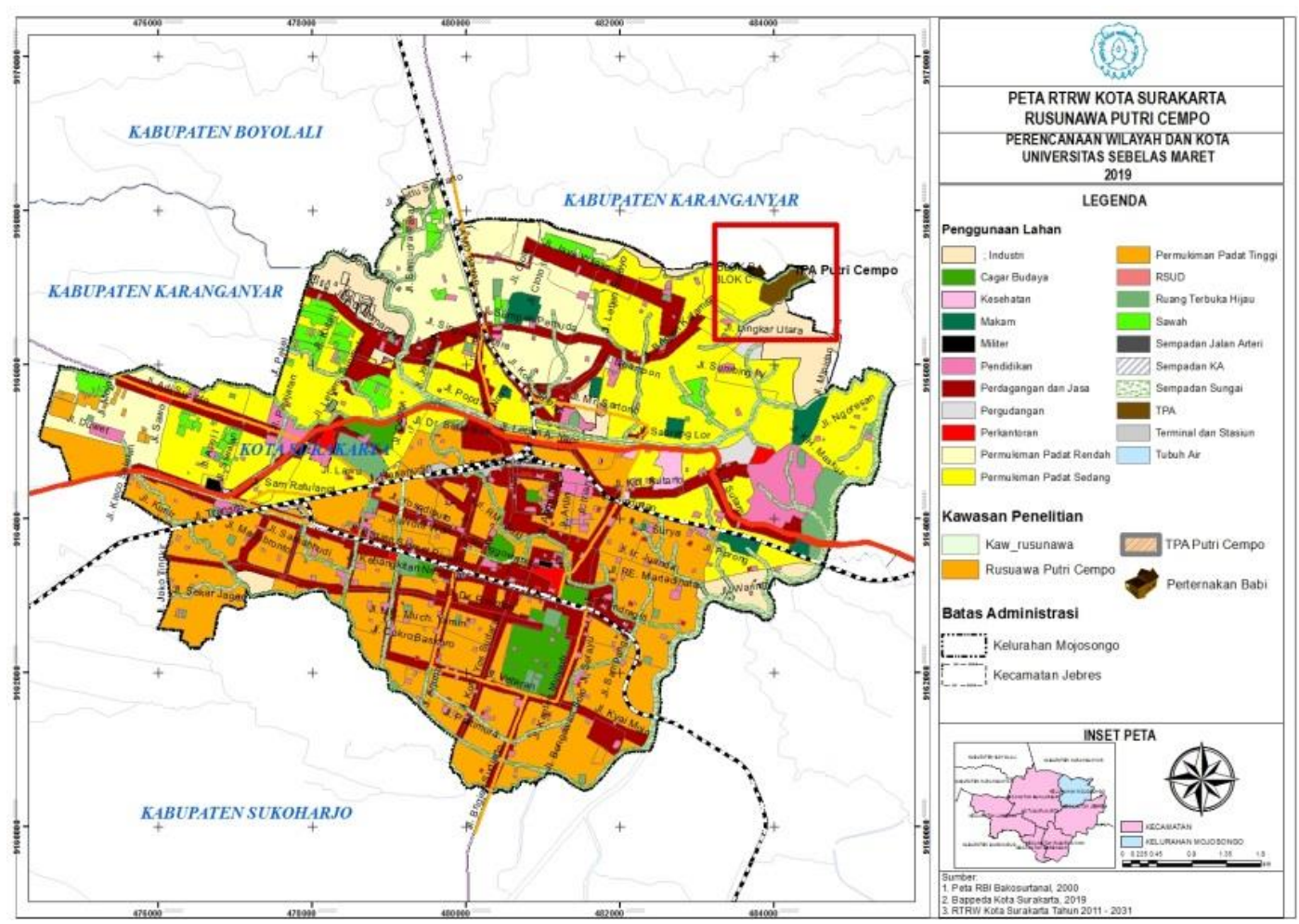

Gambar 3. Peta Lokasi Rusunawa Putri Cempo

\subsubsection{Aksesibilitas}

Aksesibilitas menjadi salah satu pertimbangan dalam pemilihan rumah susun. Aksesibilitas yang dilihat pada penelitian ini terdiri dari jarak rusunawa menuju fasitilas umum, ketersediaan transportasi umum, dan akses rusunawa menuju jalan raya. Aksesibilitas menuju lokasi rusunawa dapat dilihat pada Gambar 4. Berikut adalah data yang didapat dari hasil observasi lapangan:

a) Jarak Rusunawa menuju Jalan Raya

Akses Rusunawa Putri Cempo menuju Jl. Mayor Achmadi perlu menggunakan kendaran pribadi. Hal ini diketahui bahwa jarak menuju jalan raya terhadap Rusunawa Putri Cempo yaitu $1 \mathrm{~km}$. Namun, secara keseluruhan kondisi fisik jaringan jalan raya menuju lokasi rusunawa dapat dikatakan cukup baik. Hanya saja untuk menuju jalan masuk ke rusunawa relatif sempit dan kondisi jalan lingkungan perlu membutuhkan perbaikan.

b) Ketersediaan Transportasi Umum

Layanan transportasi umum yang tersedia di luar kawasan Rusunawa Putri Cempo hanya terdapat satu angkutan umum yaitu jalur trayek ex-angkot 07 yang berintegrasi dengan BST (Batik Solo Trans) koridor 09. Rute trayek tersebut melewati jalan sebelum masuk ke kawasan Rusunawa Putri Cempo. Namun rute BST ini tidak sampai menjangkau kawasan Rusunawa Putri Cempo.

c) Jarak Rusunawa menuju Fasilitas Umum

Secara keseluruhan akses Rusunawa Putri Cempo terhadap fasilitas umum yang tersebar di luar maupun di lingkungan rusunawa sudah memiliki akses yang baik. Penghuni rusunawa bisa menjangkau fasilitas umum dengan berjalan kaki maupun menggunakan kendaraan pribadi/umum. Hal ini dapat dilihat dalam Tabel 4. 
Tabel 4. Kondisi Akses Rusunawa Putri Cempo menuju Fasilitas Umum

\begin{tabular}{|c|c|c|}
\hline No. & Akses menuju Fasilitas umum & Keterangan \\
\hline 1 & Pelayanan Umum/Pemerintahan & $\begin{array}{l}\text { Fasilitas pelayanan umum yang tersedia di kawasan Rusunawa Putri Cempo meliputi pos } \\
\text { keamanan lingkungan, balai serbaguna dan Kantor Kelurahan Mojosongo. Akses } \\
\text { rusunawa terhadap fasilitas pelayanan umum/pemerintah mempunyai akses yang baik } \\
\text { dan bisa dijangkau dengan berjalan kaki maupun menggunakan kendaraaan } \\
\text { pribadi/umum }\end{array}$ \\
\hline 2 & Perdagangan/Ekonomi & $\begin{array}{l}\text { Fasilitas perdagangan yang ada di lingkungan sekitar Rusunawa Putri Cempo berupa } \\
\text { warung/toko klontong dan warung makan dengan jarak } 50 \mathrm{~m} \text { dari rusunawa. Penghuni } \\
\text { bisa mengaksesnya dengan berjalan kaki. Sedangkan fasilitas perdagangan dengan } \\
\text { skala besar berupa pasar memiliki akses yang baik dan mudah untuk dijangkau dengan } \\
\text { kendaraan pribadi. }\end{array}$ \\
\hline 3 & Pendidikan & $\begin{array}{l}\text { Fasilitas pendidikan di sekitar lingkungan rusunawa hanya terdapat TPA. Sedangkan } \\
\text { untuk sarana pendidikan tingkat TK, SD, SMP, dan SMA lokasinya berada diluar kawasan } \\
\text { rusunawa. Akses rusunawa menuju TPA memiliki jarak } 500 \mathrm{~m} \text { sehingga untuk } \\
\text { menjangkau fasilitas tersebut memerlukan kendaraan pribadi. Jarak antara rusunawa } \\
\text { menuju sarana pendidikan berupa TK, SD, SMP dan SMA memiliki akses yang mudah } \\
\text { dijangkau namun perlu menggunakan moda transportasi umum/pribadi karena jaraknya } \\
\text { relatif jauh yaitu 2-3 km dari rusunawa.. }\end{array}$ \\
\hline 4 & Peribadatan & $\begin{array}{l}\text { Fasilitas peribadatan di lingkungan rusunawa Putri Cempo hanya terdapat masjid. Akses } \\
\text { pencapaian dari rusunawa ke masjid tidak terlalu jauh hanya } 200 \mathrm{~m} \text { dari rusunawa. } \\
\text { Kondisi tersebut masih bisa dijangkau oleh penghuni dengan berjalan kaki. }\end{array}$ \\
\hline 5 & Kesehatan & $\begin{array}{l}\text { Fasilitas kesehatan di lingkungan rusunawa meliputi bidan, dokter praktek dan posyandu. } \\
\text { Akses Rusunawa Putri Cempo menuju ke fasilitas kesehatan memiliki akses yang baik } \\
\text { yaitu sekitar } 500 \mathrm{~m} \text { dari rusunawa sehingga perlu menggunakan kendaraan pribadi. }\end{array}$ \\
\hline 6 & RTH/Olahraga & $\begin{array}{l}\text { Fasilitas rekreasi di lingkungan rusunawa meliputi taman bermain anak dan lapangan } \\
\text { olahraga. Rusunawa Putri Cempo juga sudah tersedia taman bermain anak yang } \\
\text { diperuntukkan bagi anak-anak untuk mengisi waktu bersama teman maupun keluarga. } \\
\text { Terdapat pula lapangan olahraga yang jaraknya } 500 \mathrm{~m} \text { dari rusunawa. }\end{array}$ \\
\hline
\end{tabular}

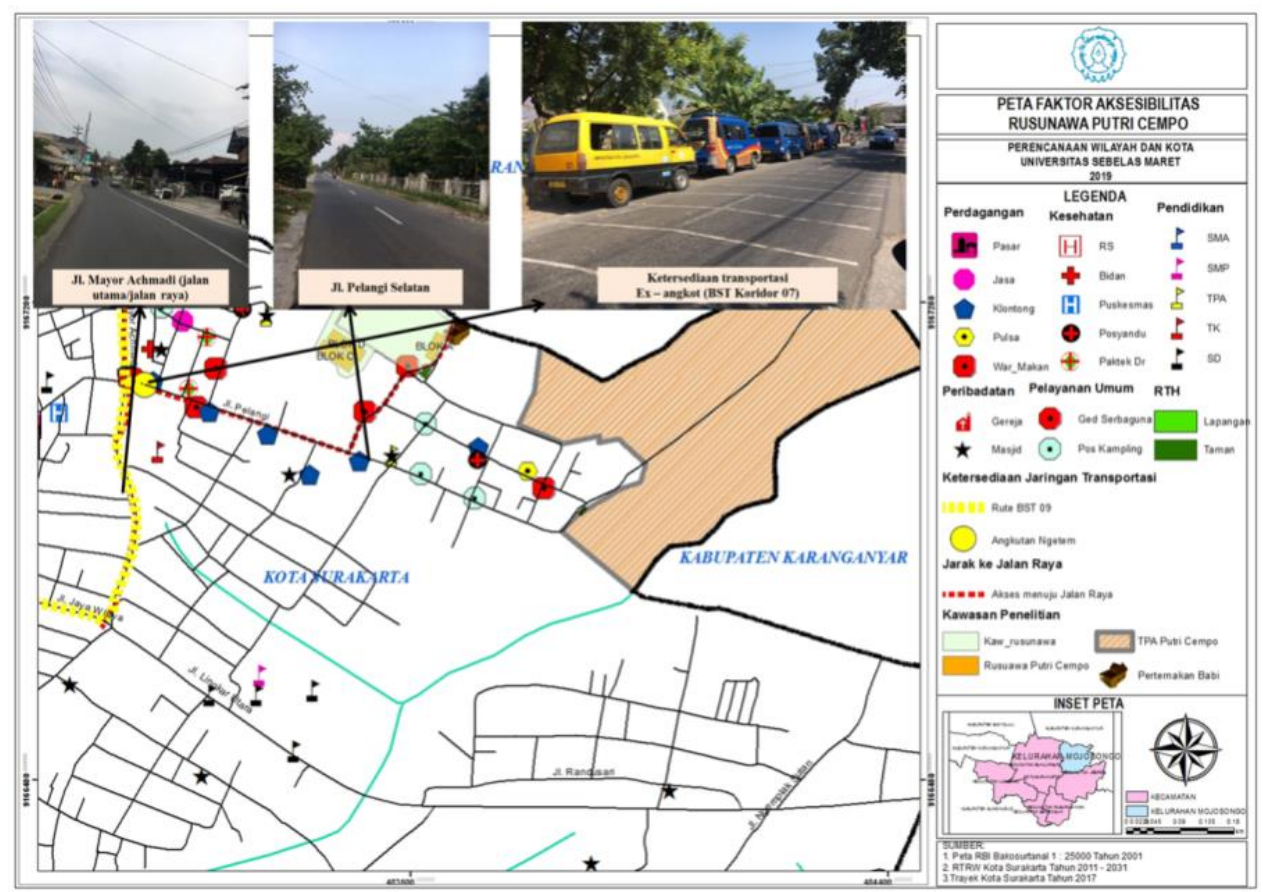

Gambar 4. Peta Aksesibilitas menuju Lokasi Rusunawa 


\subsubsection{Ketersediaan Sarana}

Rusunawa Putri Cempo sudah terlayani beberapa sarana eksisting yang tersebar di Kelurahan Mojosongo dan sarana penunjang rusunawa yang disediakan oleh Dinas Perumahan dan Permukiman Kota Surakarta untuk memenuhi kebutuhan penghuni sehari-hari. Kondisi beberapa sarana yang tersebar di lingkungan kawasan Rusunawa Putri Cempo cukup baik dalam mengakomodasi kegiatan penghuni. Tabel 5 menunjukkan persebaran sarana penunjang di Rusunawa Putri Cempo.

\section{Tabel 5. Persebaran Sarana Penunjang Rusunawa Putri Cempo}

\begin{tabular}{|c|c|c|}
\hline No. & Sarana Penunjang & Keterangan \\
\hline 1 & $\begin{array}{l}\text { Pelayanan } \\
\text { Umum/Pemerintahan }\end{array}$ & $\begin{array}{l}\text { Di lingkungan sekitar kawasan putri cempo ini sudah memiliki sarana pelayanan } \\
\text { umum/pemerintahan berupa } 2 \text { balai pertemuan dan } 4 \text { pos kamling yang tersebar di kawasan } \\
\text { tersebut. Namun untuk sarana pemerintahan berupa kelurahan dan kecamatan letaknya berada di } \\
\text { luar kawasan }\end{array}$ \\
\hline 2 & Perdagangan/Ekonomi & $\begin{array}{l}\text { Sarana perdagangan yang tersebar di lingkungan sekitar kawasan Rusunawa Putri Cempo yakni } \\
\text { toko klontong dan warung makan. Untuk sarana perdagangan dengan skala besar berupa Pasar } \\
\text { Sibela letaknya berada di luar kawasan. }\end{array}$ \\
\hline 3 & Pendidikan & $\begin{array}{l}\text { Sarana pendidikan yang terdapat di lingkungan sekitar kawasan Rusunawa Putri Cempo yakni } 1 \\
\text { TPA. Sedangkan untuk sarana pendidikan formal dengan tingkat TK, SD, dan SMA letak } \\
\text { persebarannya berada diluar kawasan. }\end{array}$ \\
\hline 4 & Peribadatan & $\begin{array}{l}\text { Sarana peribadatan di lingkungan sekitar kawasan Rusunawa Putri Cempo sudah tersedia. Sarana } \\
\text { peribadatan yang tersebar baik di luar kawasan maupun di dalam rusuawa tersebut yakni terdapat } \\
2 \text { masjid dan } 1 \text { mushola. }\end{array}$ \\
\hline 5 & Kesehatan & $\begin{array}{l}\text { Di lingkungan sekitar kawasan Rusunawa Putri Cempo sudah mempunyai sarana kesehatan untuk } \\
\text { mengakomodasi kesehatan penghuni yakni berupa posyandu, bidan, dan klinik dokter. Namun } \\
\text { untuk rumah sakit/RS berada di luar kawasan. }\end{array}$ \\
\hline 6 & RTH/Olahraga & $\begin{array}{l}\text { Ketersediaan sarana sarana RTH dan reksreasi yang tersebar di lingkungan Rusunawa Putri } \\
\text { Cempo yakni memiliki } 2 \text { taman bermain anak dan } 1 \text { lapangan. }\end{array}$ \\
\hline
\end{tabular}

\subsubsection{Ketersediaan Prasarana}

Berdasarkan yang termuat dalam SNI Tata Cara Perencanaan Lingkungan Perumahan di Perkotaan prasarana terbagi menjadi 7 (tujuh) jenis yakni jaringan jalan, jaringan drainase, jaringan telekomunikasi, jaringan persampahan, jaringan air bersih, jaringan air limbah/sanitasi, dan jaringan listrik. Di lokasi kawasan Rusunawa Putri Cempo sudah terdapat jaringan prasarana yang melayani kebutuhan penghuni (lihat Tabel 6).

Tabel 6. Kondisi Prasarana Penunjang Rusunawa Putri Cempo

\begin{tabular}{|c|c|c|}
\hline No. & $\begin{array}{l}\text { Prasarana } \\
\text { Penunjang }\end{array}$ & Keterangan \\
\hline 1 & Jalan & $\begin{array}{l}\text { Lokasi Rusunawa Putri Cempo sudah didukung dengan jaringan jalan permukiman sekitar yang } \\
\text { memadai. Jaringan jalan lingkungan di kawasan Rusunawa Putri Cempo mayoritas sudah memiliki } \\
\text { kondisi jalan yang baik, serta sudah dilapisi dengan beton dan aspal. Akan tetapi, jalan lingkungan di } \\
\text { Rusunawa Putri Cempo Blok A ini dalam kondisi rusak ringan namun hal tersebut tidak menghalangi } \\
\text { aktivitas para penghuni disana. }\end{array}$ \\
\hline 2 & Drainase & $\begin{array}{l}\text { Jaringan drainase baik di lingkungan permukiman maupun di kawasan Rusunawa Putri Cempo terbagi } \\
\text { menjadi } 3 \text { yakni saluran drainase primer berupa aliran sungai, jaringan drainase sekunder yang di Jl. } \\
\text { Mayor Achmadi, dan jaringan drainase tersier yang berada di lingkungan perumahan. }\end{array}$ \\
\hline 3 & Air Bersih & $\begin{array}{l}\text { Persediaan pelayanan air bersih Rusunawa Putri Cempo bersumber dari air tanah dibandingkan } \\
\text { menggunakan air bersih dari PDAM Kota Surakarta. Hal tersebut karena jaringan PDAM belum } \\
\text { menjangkau Rusunawa Putri Cempo. }\end{array}$ \\
\hline 4 & Telekomunikasi & $\begin{array}{l}\text { Jaringan telekomunikasi yang didistribusikan ke para provider dikelola oleh PT. Telkom dan jaringan } \\
\text { lainnya. Sehingga penghuni rusunawa lebih memilih menggunakan hanphone dibanding menggunakan } \\
\text { telepon rumah. }\end{array}$ \\
\hline 5 & Listrik & $\begin{array}{l}\text { Pelayanan jaringan listrik yang ada di Rusunawa Putri Cempo merupakan jaringan yang dikelola } \\
\text { langsung oleh Perusahan Listrik Negara (PLN) Kota Surakarta. Jaringan listrik secara umum mengikuti } \\
\text { jaringan jalan yang ada di kawasan permukiman dengan besar daya listrik } 900-1300 \text { watt. }\end{array}$ \\
\hline
\end{tabular}




\begin{tabular}{ccl}
\hline No. & $\begin{array}{c}\text { Prasarana } \\
\text { Penunjang }\end{array}$ & \multicolumn{1}{c}{ Keterangan } \\
\hline 6 & Air Limbah & $\begin{array}{l}\text { Jaringan air limbah di Rusunawa Putri Cempo berupa jaringan pembuangan air limbah setempat berupa } \\
\text { septic tank (on site) } \\
\text { Sistem pengelolaan sampah ini dikelola oleh Dinas Lingkungan Hidup Kota Surakarta (DLH) dimulai dari } \\
\text { skala terkecil yang ada di kelurahan dengan mendatangi rumah warga termasuk rusunawa yang diangkut } \\
\text { menngunakan mobil sampah. }\end{array}$ \\
\hline
\end{tabular}

\subsubsection{Kondisi Demografi}

Kondisi demografi pada pemilihan lokasi rusunawa ini ditinjau dari segi kepadatan penduduk. Kepadatan penduduk yang digunakan adalan kepadatan penduduk netto. Kepadatan penduduk netto bertujuan untuk mengetahui persebaran penduduk suatu wilayah dan penataan ruang khususnya distribusi permukiman pada lahan terbangun. Untuk mengetahui kepadatan penduduk di Kelurahan Mojosongo agar bisa dibangunnya sebuah rusunawa dapat dihitung menggunakan rumus kepadatan penduduk netto (lihat Tabel 7). Data jumlah penduduk dan luas wilayah Kelurahan Mojosongo yang digunakan adalah Kecamatan Jebres Dalam Angka tahun 2015-2018.

Tabel 7. Kepadatan Penduduk Netto di Kecamatan Jebres

\begin{tabular}{lccccc}
\hline \multirow{2}{*}{ Kelurahan } & Luas permukiman & \multicolumn{4}{c}{ Kepadatan penduduk (jiwa/km2) } \\
\cline { 3 - 6 } & $\mathbf{( k m 2 )}$ & $\mathbf{2 0 1 5}$ & $\mathbf{2 0 1 6}$ & $\mathbf{2 0 1 7}$ & $\mathbf{2 0 1 8}$ \\
\hline Kepatihan Kulon & 0.09 & 29691 & 28159 & 26714 & 25347 \\
Kepatihan Wetan & 0.05 & 60574 & 58085 & 55702 & 53426 \\
Sudiroprajan & 0.12 & 36700 & 34403 & 32247 & 30226 \\
Gandekan & 0.29 & 33102 & 32808 & 32514 & 32223 \\
Sewu & 0.30 & 24874 & 24626 & 24384 & 24142 \\
Pucangsawit & 0.57 & 24095 & 24114 & 24135 & 24156 \\
Jagalan & 0.45 & 27166 & 27009 & 26853 & 26699 \\
Purwodinigratan & 0.18 & 29611 & 29059 & 28518 & 27989 \\
Tegalharjo & 0.21 & 26230 & 24948 & 23728 & 22569 \\
Jebres & 1.48 & 22089 & 22253 & 22417 & 22582 \\
Mojosongo & $\mathbf{3 . 5 4}$ & $\mathbf{1 4 2 6 2}$ & $\mathbf{1 4 4 2 3}$ & $\mathbf{1 4 5 8 5}$ & $\mathbf{1 4 7 5 0}$ \\
\hline
\end{tabular}

Pada analisis netto tahun 2016, kelurahan yang memiliki kepadatan terendah yaitu Kelurahan Mojosongo sebesar 14.423 jiwa $/ \mathrm{km}^{2}$ dalam satu kelurahan. Jadi dapat disimpulkan melalui perhitungan di atas diketahui bahwa kondisi Kelurahan Mojosongo yang memiliki kepadatan rendah ini bisa mempengaruhi jenis hunian yang akan dibangun disana sehingga memang memiliki potensi sebagai kelurahan yang cocok dalam pengembangan perumahan.

\subsubsection{Kondisi Lingkungan}

Kondisi lingkungan Rusunawa Putri Cempo dari segi kenyamanan cukup memberikan dampak negatif karena terdapat perternakkan babi dan jaraknya tidak terlalu jauh dari tempat pembuangan akhir. Ada 3 hal yang perlu diperhatikan terkait kondisi lingkungan dalam pemilihan lokasi rusunawa yakni pencemaran udara, pencemaran air dan kebisingan.

\section{a) Pencemaran Udara}

Berdasarkan hasil observasi ditemukan bahwa Rusunawa Putri Cempo memiliki lokasi yang berdekatan dengan TPA Putri Cempo dan perternakkan babi sehingga dapat menimbulkan polusi dari kegiatan tersebut. Menurut data dari DLH Kota Surakarta mengenai kualitas udara di sekitar TPA Putri Cempo telah melakukan uji melalui 3 titik lokasi yaitu lokasi TPA, jalan masuk TPA dan permukiman sekitar TPA. Berdasarkan hasil pengukuran terhadap kualitas udara di permukiman sekitar TPA termasuk Rusunawa Putri Cempo belum dapat dikatakan tercemar meski hasil uji menunjukkan bahwa nilai kualitas udara cenderung jelek namun masih di bawah baku mutu. 


\section{b) Pencamaran Air}

Air lindi merupakan air yang berisi kandungan organik tinggi yang terbentuk akibat timbunan sampah yang melarutkan banyak senyawa akibat adanya air hujan yang meresap ke dalam landfill. Apabila penanganan dan pengolahan air lindi sampah tidak dilakukan secara optimal, air lindi ini akan masuk ke dalam air tanah ataupun ikut terbawa dalam aliran permukiman. Sementara itu, kebutuhan air bersih di kawasan Rusunawa Putri Cempo dilayani oleh jaringan air bersih yang bersumber dari air tanah. Hasil pengujian air lindi menunjukkan bahwa air lindi di TPA Putri Cempo sudah tercemar oleh kandungan COD yang melampaui nilai baku mutu. Namun tidak berpengaruh pada kondisi air tanah yang ada di permukiman sekitar TPA Putri Cempo.

c) Kebisingan

Berdasarkan hasil data perhitungan yang dilakukan oleh Dinas Lingkungan Hidup dilakukan uji pada ke tiga titik sampel dalam sekitar lokasi yaitu di dalam lokasi TPA, lokasi masuk dan di lokasi permukiman TPA. Untuk tingkat kebisingan di kawasan permukiman TPA Putri Cempo menunjukkan nilai sebesar 55,6 dB dari $70 \mathrm{~dB}$. Nilai tersebut termasuk dalam kategori sedang.

\subsubsection{Harga Lahan}

Harga lahan tahun 2016 saat Rusunawa Putri Cempo blok A dibangun yaitu Rp.1.636.382.000 dengan harga per meternya Rp.288.858 berdasarkan harga pasar ganti rugi. Lahan tersebut dibeli oleh pemerintah Kota Surakarta seluas $5.665 \mathrm{~m}^{2}$. Nilai tersebut tergolong murah dikarenakan berada di pinggiran kota sekaligus dengan dengan TPA. Pemerintah Kota Surakarta juga tidak masalah apabila membeli lahan tersebut berdasarkan harga NJOP. Berdasarkan data Peta Zona Nilai tanah Tahun 2018 dari Kementerian ATR/BPN, sampel untuk harga lahan di Kelurahan Mojosongo dapat dilihat pada Tabel 8.

\section{Tabel 8. Sampel Nilai Lahan di Kelurahan Mojosongo}

\begin{tabular}{clc}
\hline No. & \multicolumn{1}{c}{ Lokasi } & Harga Lahan (Rp/m2) \\
\hline 1 & Perumahan di Jl. Letjend Sutoyo & 3.276 .000 \\
2 & Perumahan di Jl, Jaya Wijaya & 2.780 .000 \\
3 & Permukiman di lingkungan TPA Putri Cempo & 843.932 \\
\hline \multicolumn{2}{c}{ Sumber: Zona Nilai Tanah di Kelurahan Mojosongo oleh Kementerian ATR/BPN, 2019 }
\end{tabular}

\subsection{IDENTIFIKASI FAKTOR PEMILIHAN LOKASI RUSUNAWA PUTRI CEMPO}

Pada analisis faktor yang mempengaruhi pemilihan lokasi Rusunawa Putri Cempo menggunakan teknik Analytical Hierarchy Process (AHP) dengan bantuan aplikasi Expert Choice 11. Penggunaan aplikasi Expert Choice 11 dilakukan dengan menginput hasil data kuisioner yang telah diberikan setiap stakeholder. Setelah itu, menghasilkan output berupa faktor prioritas yang mempengaruhi pemilihan lokasi Rusunawa Putri Cempo. Gambar 5 merupakan hasil dari tingkatan prioritas faktor yang mempengaruhi pemilihan lokasi Rusunawa Putri Cempo.

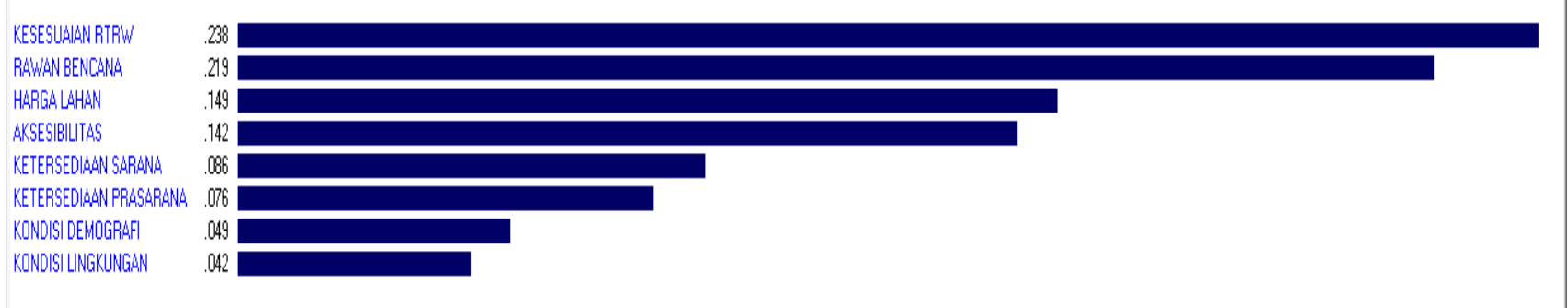

Gambar 5. Tingkat Prioritas Faktor yang Mempengaruhi Pemilihan Lokasi Rusunawa Putri Cempo 


\subsubsection{Prioritas I: Faktor Kesesuaian dengan Rencana Tata Ruang}

Kesesuaian dengan rencana tata ruang sangat diperlukan dalam arahan pengembangan wilayah termasuk pengembangan wilayah untuk kawasan perumahan. Hal ini didukung dengan pendapat Komarudin (1997) dan Catanese, dkk (1991) yang menyatakan bahwa beberapa sumber regulasi terkait pembangunan perumahan seperti SNI tata cara perencanaan lingkungan perumahan, pedoman penataan ruang kawasan budidaya (2007) dan UU No. 20 tahun 2011 tentang rumah susun yang menyatakan pembangunan perumahan harus sah secara hukum dan sesuai dengan arahan pemanfataan ruang yang mana sudah diatur dengan rencana tata ruang wilayah.

Berdasarkan hasil analisis, kesesuaian dengan rencana tata ruang merupakan faktor yang berada diposisi pertama dalam pemilihan lokasi Rusunawa Putri Cempo. Faktor kesesuian dengan rencana tata ruang dianggap sebagai faktor utama yang memiliki pengaruh penting sebab dalam pembangunan perumahan perlu adanya acuan pada wilayah yang telah ditetapkan sebagai peruntukkan kawasan budidaya perumahan. Acuan ini nantinya akan menyangkut serangkaian perizinan.

\subsubsection{Prioritas II: Faktor Kerawanan Bencana}

Dalam pelaksanaan pembangunan baik infrastruktur maupun hunian perlu memperhitungkan aspek kebencanaan untuk mengantisipasi terjadinya risiko kerawanan bencana. Kerawanan bencana dalam pemilihan lokasi Rusunawa Putri Cempo didukung oleh beberapa bendapat dari Komarudin (1997) dan Budiharjo (2007) serta sumber regulasi dari Kepmenkes (1999) dan DPU (2007) yang menjelaskan bahwa pemilihan lokasi hunian baik rumah tinggal maupun rumah susun harus aman dan terhindar dari potensi bencana alam seperti banjir, gempa bumi, dan longsor.

Tingkat prioritas kepentingan kerawanan bencana menempati urutan kedua. Hal ini menunjukkan bahwa faktor kerawanan bencana merupakan faktor yang cukup penting dan berpengaruh serta menjadi perhatian bagi Pemerintah Kota Surakarta dalam pemilihan lokasi Rusunawa. Pada saat pengajuan untuk penambahan rusunawa ke Pemerintah Pusat, Pemerintah Kota Surakarta harus memenuhi syarat dan ketentuan yang berlaku dalam pengajuan lahan. Lahan yang diajukan oleh Pemerintah Kota Surakarta ke Pemerintah Pusat sifatnya sudah clean and clear. Clean dalam persyaratan lahan yang harus dipenuhi adalah lahan kosong yang terhindar dari bencana, dan clear artinya status lahan tersebut jelas milik Pemerintah Kota Surakarta.

\subsubsection{Prioritas III: Faktor Harga Lahan}

Harga lahan menjadi salah satu pertimbangan pemilihan lokasi perumahan. Faktor penentu harga lahan untuk perumahan didukung dengan adanya pendapat dari beberapa ahli seperti Nasucha (1995), dan Catanesse, dkk (1991) yang menerangkan bahwa harga lahan untuk perumahan cenderung lebih murah apabila berada di pinggiran kota dan lain halnya dengan harga lahan yang mempunyai aksesibilitas tinggi seperti dekat dengan pusat kota yang cenderung lebih mahal.

Faktor harga lahan menempati tingkat prioritas ke tiga. Hal ini menunjukkan bahwa faktor harga lahan memiliki peran cukup penting karena berpengaruh pada kondisi lahan yang masih tersedia di Kota Surakarta. Harga lahan yang dibangun untuk Rusunawa Putri Cempo tergolong murah karena kondisi lahan yang berada di dekat TPA dan di pinggiran kota. Pemerintah Kota Surakarta tidak punya pilihan lain selain menempatkan rusunawa disana. Hal ini dikarenakan keterbatasan lahan di Kota Surakarta yang semakin terbatas. Selain itu, pembangunan Rusunawa Putri Cempo ini dibangun sebagai fasilitas publik dengan segmentasi pasar menegah ke bawah yang mematok harga sewa rendah.

\subsubsection{Prioritas IV: Faktor Aksesibilitas}

Kemudahan aksesibilitas dalam pemilihan lokasi hunian didukung oleh beberapa pendapat dari Komarudin (1997), Nasucha (1995), Lusht (1997), Drabkin (1980), Catanesse, dkk (1991) serta regulasi terkait pemilihan lokasi perumahan dari standar Kepmenkes (1999) dan SNI tata cara perencanaan lingkungan perumahan yang secara garis besar menyatakan bahwa pemilihan lokasi perumahan maupun rumah susun perlu mempertimbangkan aspek aksesibilitas yang erat kaitannya dengan ketersediaan transportasi umum, jarak menuju jalan raya, dan jarak menuju fasilitas umum. 
Berdasarkan hasil analisis menunjukkan bahwa tingkat prioritas kepentingan aksesibilitas menempati urutan ke empat yang artinya faktor ini cukup penting dalam pemilihan lokasi Rusunawa Putri Cempo. Faktor aksesibilitas yang dilihat dalam pemilihan lokasi Rusunawa Putri Cempo meliputi ketersediaan transportasi umum, jarak menuju jalan raya dan jarak menuju fasilitas umum. Ketersediaan tranportasi dalam pemilihan lokasi Rusunawa Putri Cempo didukung dengan keberadaan transportasi umum berupa BST Koridor 09 yang akan memudahkan penghuni menuju fasilitas tertentu. Selain itu, Rusunawa Putri Cempo sudah memiliki akses yang terbilang cukup baik untuk menuju jalan raya/jalan utama yaitu Jl. Mayor Achmadi. Hanya saja lokasi yang terpencil merupakan kekurangan dari Rusunawa Putri Cempo. Tentunya hal ini dapat mempersulit masyarakat atau pendatang yang ingin ke rusunawa tersebut. Persoalan ini akan diatasi oleh Pemerintah Kota Surakarta dengan membangun ruas jalan lingkungan yang dihubungkan dengan jalan lingkungan permukiman sekitar.

\subsubsection{Prioritas V: Faktor Ketersediaan Sarana}

Dalam penyediaan perumahan untuk seluruh lapisan masyarakat dengan tingkat ekonomi apapun perlu ditunjang dengan ketersediaan sarana guna mendukung aktivitas penghuni. Berdasarkan pendapat dari beberapa ahli menurut Komarudin (1997), Drabkin (1980), Catanesse, dkk (1991), Turner (1976), Budiharjo (2004), Williams (2008) menyatakan bahwa lokasi perumahan memiliki kedekatan dengan kelengkapan pelayanan sarana.

Berdasarkan hasil analisis menunjukkan bahwa faktor ketersediaan sarana menempati urutan ke lima. Faktor ketersediaan sarana kurang memiliki pengaruh besar dalam pemilihan lokasi Rusunawa Putri Cempo. Hal ini dikarenakan Rusunawa Putri Cempo telah terlayani sarana eksisting yang tersebar di Kelurahan Mojosongo. Kelengkapan sarana untuk pemenuhan kebutuhan perumahan yang layak huni bagi MBR menurut Syarief (2000) dan De'Chiara (1995) didukung dengan sarana penunjang seperti kesehatan, pendidikan, perekonomian, peribadatan, pelayanan umum serta rekreasi. Standar dalam penyediaan sarana penunjang rumah susun mengacu pada SNI tata cara perencanaan lingkungan perumahan di perkotaan yang terdiri pendidikan, peribadatan, kesehatan, perniagaan/ekonomi, pemerintahan/pelayanan umum, dan RTH/olahraga. Pembangunan rumah susun sederhana sewa merupakan program dari pemerintah pusat sehingga segala penyediaan sarana penunjang rusunawa telah disediakan saat pembangunan seperti sarana peribadatan, sarana RTH/olahraga, dan sarana untuk tempat pertemuan warga. Secara keseluruhan dalam penyediaan sarana penunjang untuk Rusunawa Putri Cempo telah terlayani sarana yang telah disediakan oleh Pemerintah Kota Surakarta maupun sarana yang berada diluar rusunawa.

\subsubsection{Prioritas VI: Faktor Ketersediaan Prasarana}

Dalam memberikan pelayanan bagi masyarakat berpenghasilan rendah untuk memperoleh kebutuhan hunian yang layak huni tidak dapat terlepas dari aspek ketersediaan prasarana dasar penunjang perumahan. Hal ini didukung oleh pendapat dari beberapa pakar menurut Komarudin (1997), Drabkin (1980), Catanesse, dkk (1991), Turner (1976), Budiharjo (2004), Williams (2008) yang menyatakan bahwa dalam pemilihan lokasi perumahan perlu ditunjang dengan kelengkapan prasarana. Prasarana penunjang perumahan merupakan elemen utama demi terselenggaranya kegiatan perumahan. Adapun jenis prasarana dasar penunjang rumah susun yang mengacu pada ketentuan SNI 03-1733-2004 tentang Tata Cara Perencanaan Lingkungan Perumahan di Perkotaan dimana wajib disediakan oleh pemerintah untuk lingkungan perumahan yang layak huni yaitu air bersih, air limbah, drainase, listrik, persampahan, jalan dan telekomunikasi.

Berdasarkan kondisi di lapangan, Rusunawa Putri Cempo telah ditungang oleh prasarana eksisting permukiman. Hasil analisis menunjukkan bahwa faktor ketersediaan prasarana menempati urutan ke enam. Hal ini diketahui bahwa dalam penyediaan prasarana baik perumahan maupun rusunawa merupakan tanggung jawab Pemerintah Kota Surakarta yang ditangani oleh Dinas Perumahan dan Permukiman. Dinas Perumahan dan Permukiman saling bekerja sama dengan dinas lainnya seperti PLN dalam menyediakan pasokan listrik, pembangunan jaringan drainase oleh DPU dan PDAM yang menyediakan pelayanan air bersih.

\subsubsection{Prioritas VII: Faktor Kondisi Demografi}

Berdasarkan Permen PUPR No. 01/PRT/M/2018 tentang Bantuan Pembangunan dan Pengelolaan Rumah Susun dan UU No. 20 tahun 2011 tentang Rumah Susun menyebutkan bahwa dalam pemilihan lokasi rumah susun perlu mempertimbangkan kepadatan penduduk di dalam satu wilayah yang memiliki kepadatan permukiman tertentu dan dikatakan mampu untuk menampung pembangunan rumah susun. Faktor kondisi demografi merupakan tingkat kepentingan ke tujuh yang kurang 
dipertimbangkan dari faktor lainnya. Faktor kondisi demografi hanya faktor pendukung yang dijadikan sebagai acuan dalam pemilihan lokasi Rusunawa Putri Cempo oleh Pemerintah Kota Surakarta. Dari hasil perhitungan memperlihatkan bahwa Kelurahan Mojosongo memiliki kepadatan penduduk permukiman dengan tingkat kepadatan rendah. Kondisi tersebut bukan menjadi dasar dibangun rusunawa sebab permukiman dengan kepadatan rendah bisa mempengaruhi pembangunan perumahan secara horizontal. Akan tetapi pada dasarnya pembangunan rusunawa dibangun pada wilayah dengan kepadatan permukiman tinggi. Untuk pembangunan Rusunawa Putri Cempo faktornya bukan karena kepadatan permukiman tinggi, tetapi karena ada aset berupa lahan milik Pemerintah Kota Surakarta di Kelurahan Mojosongo. Selain itu, Pemerintah Kota Surakarta memilih Kelurahan Mojosongo sebagai wilayah yang dikembangkan untuk perumahan vertikal berupa rusunawa. Namun dalam pemilihan lokasi tersebut perlu melihat ketersediaan lahan yang sesuai kriteria untuk dibangun rusunawa.

\subsubsection{Prioritas VIII: Faktor Kondisi Lingkungan}

Kondisi lingkungan dianggap sebagai salah satu yang penting untuk dipertimbangkan dalam pemilihan lokasi perumahan maupun rumah susun dikarenakan akan berdampak pada kehidupan penghuni kedepannya. Hal ini didukung oleh pendapat Rapoport (1983), dan Balbontin, de Dios Ortuzar dan Swait (2014), Drabkin (1980), Turner (1976), dan Budihardjo (2004) yang menyatakan dalam pemilihan lokasi rumah tinggal atau rumah susun perlu mempertimbangkan kualitas lingkungan dimana lokasi tersebut bukan daerah yang dapat menimbulkan pencemaran atau polusi.

Faktor kondisi lingkungan merupakan faktor yang berada diperingkat terakhir yang artinya faktor ini dianggap tidak diprioritaskan atau tidak sama sekali memiliki pengaruh dalam pemilihan lokasi Rusunawa Putri Cempo. Pada faktanya, pemilihan lokasi Rusunawa Putri Cempo belum mempertimbangkan faktor kondisi lingkungan karena lokasinya yang berada dalam radius $700 \mathrm{~m}$ terhadap area pembuangan sampah Putri Cempo dan $50 \mathrm{~m}$ dari perternakkan babi. Melihat kondisi ini tentunya berdampak kepada penghuni rusunawa yang merasakan ketidaknyamanan dari aktivitas tersebut. Terlepas dari kelebihan dan kekurangan Pemerintah Kota Surakarta dalam memberikan hunian layak huni bagi MBR, seharusnya kondisi tersebut tidak memenuhi syarat. Akan tetapi permasalahannya adalah ketersediaan lahan yang memenuhi syarat untuk dibangun rusunawa berada dekat dengan TPA Putri Cempo. Hal ini mengindikasi bahwa Pemerintah Kota Surakarta lebih mempertimbangkan lokasi ketersediaan lahan dibandingkan kondisi lingkungan. Sehingga faktor kondisi lingkungan dianggap lebih rendah dari faktor lain dalam pemilihan lokasi rusunawa. Apabila ada batasan mengenai lokasi rusunawa tidak berada di dekat area yang berpolusi diharapkan bisa terpenuhi. Mengingat kebutuhan akan tempat tinggal di Kota Surakarta tinggi sehingga untuk melaksanakan pembangunan dibentuk dari ketersediaan lahan terlebih dahulu.

\section{KESIMPULAN}

Pembangunan rusunawa pada hakikatnya dibangun untuk mengatasi permukiman kumuh dengan menyediakan hunian layak huni dengan harga terjangkau bagi masyarakat berpenghasilan rendah (MBR) dan menjamim kesehatan masyarakatnya. Pemerintah Kota Surakarta telah membangun rusunawa di Kelurahan Mojosongo yaitu Rusunawa Putri Cempo yang terdiri dari 4 (empat) blok. Pembangunan Rusunawa Putri Cempo mengindikasi belum sesuai dengan standar atau teori terkait pemilihan lokasi rumah susun. Hal ini bisa dibuktikan dari kondisi eksisting lokasi Rusunawa Putri Cempo yang berada dalam radius dekat dengan Tempat Pembuangan Akhir (TPA) Putri Cempo dan perternakkan babi.

Berdasarkan hasil analisis yang telah dilakukan dapat disimpulkan bahwa terdapat 4 urutan prioritas faktor utama yang mempengaruhi pemilihan lokasi Rusunawa Putri Cempo yaitu kesesuaian dengan rencana tata ruang, kerawanan bencana, harga lahan dan aksesibilitas. Selain itu, terdapat 4 faktor yang tidak mempunyai pengaruh besar yang juga sebagai acuan dalam pemilihan lokasi Rusunawa Putri Cempo yaitu, ketersediaan sarana, ketersediaan prasarana, kondisi demografi dan kondisi lingkungan. Urutan faktor prioritas di atas sudah saling berkaitan dengan tidak mengabaikan faktor prioritas dalam pemilihan lokasi Rusunawa Putri Cempo sehingga dalam pemilihan lokasi rumah susun dapat dilakukan secara tepat sesuai regulasi maupun teori. Berdasarkan urutan faktor prioritas yang telah dijabarkan di atas ditemukan bahwa faktor kondisi lingkungan bukan menjadi pertimbangan utama bagi Pemerintah Kota Surakarta dalam pemilihan lokasi Rusunawa Putri Cempo. Hal ini dikarenakan bahwa pada prinsipnya pemerintah Kota Surakarta untuk membangun rusunawa adalah melihat ketersediaan lahan yang mampu untuk dibangun rusunawa dengan status kepemilikan milik aset Pemerintah Kota Surakarta. 
Adapun beberapa rekomendasi yang diperlukan untuk memperbaiki kelemahan yang terdapat dalam faktor yang mempengaruhi pemilihan lokasi Rusunawa Putri Cempo. Berikut beberapa rekomendasi yang diusulkan untuk beberapa pihak agar menjadi pertimbangan Pemerintah Kota Surakarta dalam memilih lokasi Rusunawa Putri Cempo adalah sebagai berikut:

a) Rekomendasi untuk Pemerintah

- Untuk pembangunan rusunawa selanjutnya perlu mempertimbangkan minimal faktor kondisi lingkungan sekitar dalam pemilihan lokasi rusunawa karena ini menyangkut kesejahteraan penghuni rusunawa.

- Memberikan papan pentunjuk/signage lokasi Rusunawa Putri Cempo

- Pemerintah selaku penyedia tempat tinggal layak huni bagi masyarakat berpenghasilan rendah perlu memberikan jaminan kepada para penghuni Rusunawa Putri Cempo yang sewaktu-waktu akan mengeluh atas ketidaknyamanan yang ditimbulkan dari aktivitas persampahan dan perternakkan babi.

- Untuk mengurangi suara bising yang ditimbulkan dari aktivitas persampahan pemerintah perlu berinisiatif melakukan penanaman pohon di sepanjang jalan lingkungan karena pohon bisa membantu menyerap suara.

b) Rekomendasi untuk Penelitian Selanjutnya

- Untuk penelitian selanjutnya diharapkan dapat mengambil studi kasus kearah pemetaan penentuan lokasi pembangunan rusunawa pada kawasan mixed use di Kota Surakarta. mengingat kondisi Kota Surakarta yang semakin bertambah padat.

Selain isu terkait pemilihan lokasi Rusunawa Putri Cempo, untuk penelitian selanjutnya diharapkan bisa meneliti tingkat kenyamanan penghuni terhadap kondisi lingkungan Rusunawa Putri Cempo.

\section{UCAPAN TERIMA KASIH}

Penulis mengucapkan terimakasih kepada keluarga besar Prodi Perencanaan Wilayah dan Kota, Universitas Sebelas Maret yang telah mendukung penulis dalam penyusunan jurnal ini.

\section{DAFTAR PUSTAKA}

Budiharjo, E. (1994). Percikan Masalah Arsitektur, Perumahan Perkotaan. Yogyakarta: Gajah Mada University Press.

Catanesse, A. J. \& Synder, J. C. (1996). Perencanaan Kota. Jakarta: Erlangga.

Chiara, J. D. (1995). Time Saver Standars for Housing and Residential Development Second. Singapore: McGraw-Hill Book Co.

Drabkin, D. H. (1980). Land Policy and Urban Growth. Great Britain: Pregamen Press.

Hashim, A. E., Samikom, S. A., Nasir, N. M., \& Normazwin, I. (2012). Assessing Factors Influencing Performance of Malaysian Low-Cost Public Housing in Sustainable Environment, Social and Sciences, 50, 920-927. DOI: 10.1016/j.sbspro.2012.08.093

Kadir, A. et al. (2013). Analisis Stakeholder Pengelolaan Taman Nasional Bantimurung Bulusaurung, Provinsi Sulawesi Selatan, Jurnal Manusia dan Lingkungan, 20(1), 11-21. Diakses dari https://jurnal.ugm.ac.id/JML/article/view/18470

Keputusan Menteri Kesehatan Repubik Indonesia Nomor 829/Menkes/SK/VII/1999. Persyaratan Kesehatan Perumahan. Diakses dari https://peraturan.bkpm.go.id/jdih/userfiles/batang/KEPMENKES_829_1999.pdf

Komarudin. (1997). Menelusuri Pembangunan Perumahan dan Permukiman. Jakarta: Yayasan Real Estate Indonesia.

Lusht, K. M. (1997). Real Estate Valuation Priciples and Application. Chicago: Irwin.

Nasucha, C. (2001). Politik Ekonomi Pertanahan dan Struktur Perpajakan Atas Tanah. Jakarta: Kesaint Blanc.

Ortuzar, D. D. J., Balbontin, C., \& Swait, J. D. (2014). Importance of Dwelling, Neigbourhood Attributes in Residential Location Modelling: Best Wosrt Scaling vs. Discrete Choice, Social and Behavioral Science, 160, 92-101. DOI: 10.1016/j.sbspro.2014.12.120

Peraturan Daerah Kota Surakarta Nomor 1 Tahun 2012 tentang Rencana Tata Ruang Wilayah Kota Surakarta Tahun 2011 - 2031. Diakses dari https://pusdataru.jatengprov.go.id/dokumen/RTRW-Prov/13-Kota-Surakarta/PERDA-NO-1-TH-2012-KOTA-SURAKARTA.pdf

Peraturan Menteri Pekerjaan Umum dan Perumahan Rakyat Republik Indonesia Nomor 01/PRT/M/2018 Tentang Bantuan Pembangunan dan Pengelolaan Rumah Susun. Diakses dari https://sirusun.perumahan.pu.go.id/web/wp-content/uploads/2018/11/PERMEN-01PRT-M-2018-BANTUAN-DAN-PENGELOLAAN-RUMAH-SUSUN.pdf

Peraturan Menteri Pekerjaan Umum Nomor 41/PRT/M/2007 Tentang Pedoman Kriteria Teknis Kawasan Budidaya. Diakses dari http://landspatial.bappenas.go.id/komponen/peraturan/the_file/permen41.pdf 
Peraturan Walikota Kota Surakarta Nomor 27-C Tahun 2016 Tentang Kedudukan, Susunan. Organisasi, Tugas, Fungsi dan Tata Kerja. Diakses dari http://jdih.surakarta.go.id/jdihsolo/proses/produkhukum/file/6079_PERWALI_NO_27-C_TAHUN_2016.pdf

Rapoport, A. (1983). The Meaning of The Built Environment. Beverly Hills: Sage Publications.

Revi, A. \& Dube, M. (1999). Indicators for urban environmental services in Lucknow - process and methods, SAGE Journals Environment and Urbanization, 11(2), 227-246.DOI: 10.1177/095624789901100218

Rusdiono, T. P. (2012). Hubungan Lokasi Rumah Susun Terhadap Tingkat Kesejahteraan Penghuni Rumah Susun di Kota Surakarta (Studi Kasus Rusunawa Begalon, Semanggi dan Jurug), Skripsi. Surakarta: Universitas Sebelas Maret

SNI 03-1733-2004 Tentang Tata Cara Perencanaan Lingkungan Perumahan di Perkotaan. Diakses dari http://sni.litbang.pu.go.id/index.php?r=/sni/new/sni/detail/id/694

SNI 03-7013-2004 Tentang Tata Cara Perencanaan Fasilitas Lingkungan Rumah Susun Sederhana. Diakses dari http://sni.litbang.pu.go.id/index.php?r=/sni/new/sni/detail/id/696

Syarif, Z. (2000). Kebijakan Pemerintah di Bidang Perumahan dan Permukiman bagi Masyarakat Berpenghasilan Rendah. Medan: USU Press.

Turner, J. F. (1976). Housing By People - Towards Autonomy In Building Environments. London: Marion Boyars.

Undang-Undang No. 21 Tahun 2011 tentang Pedoman Bantuan Rumah Susun Sewa. Diakses dari http://ditjenpp.kemenkumham.go.id/arsip/bn/2011/bn643-2011.pdf

Undang-Undang Nomor 1 Tahun 2011 Tentang Perumahan dan Kawasan Permukiman. Diakses dari https://www.bphn.go.id/data/documents/11uu001.pdf

Undang-Undang Nomor 20 Tahun 2011 Tentang Rumah Susun. Diakses dari http://pugpupr.pu.go.id/_uploads/PP/UU.\%20No.\%2020\%20Th.\%202011.pdf

Williams, A., Kitchen, P., Randall, J., \& Muhajarine, N. (2008). Changes in quality of life perceptions in Saskatoon, Saskatchewan: comparing survey results from 2001 and 2004, Social Indicators Research, 85(1),5-22. DOI: 10.1007/s11205-007-9129-z 